\begin{tabular}{c|c}
\multirow{2}{*}{ EESD'15 } & The $7^{\text {th }}$ International Conference on Engineering Education for Sustainable Development \\
\cline { 2 - 2 } & Vancouver, Canada, June 9 to 12, 2015
\end{tabular}

\title{
MULTIDIMENSIONAL SUSTAINABILITY ASSESSMENT OF SOLAR PRODUCTS: EDUCATING ENGINEERS AND DESIGNERS
}

\author{
Bas Flipsen ${ }^{1,2}$, Conny Bakker ${ }^{1}$ and Martin Verwaal ${ }^{1}$ \\ ${ }^{1}$ Delft University of Technology, Netherland \\ 2 s.f.j.flipsen@tudelft.nl
}

\begin{abstract}
Since 2008 the faculty of Industrial Design Engineering at the TU Delft hosts the minor Sustainable Design Engineering. The minor has been highly useful as a platform to pilot new ways of teaching engineering for sustainable development. Instead of having students make life cycle assessments and introduce them to straightforward checklists to improve their product designs, we challenge our students to develop a critical understanding of sustainability and use multidimensional assessments. Sustainability is not just about environmental benefits but also about useful products and added value. This paper describes our educational approach in the photovoltaics practicum (part of the minor). Our objective is to illustrate how such a multidimensional assessment works in practice and how it has helped students to develop a more critical, systemic perspective on sustainability. Students are asked to evaluate a PV-powered product on its sustainability by assessing the technology, usability and the environmental impact. To date, over 150 students have followed the minor, which gives us a large database of multidimensional assessments on a wide range of PV powered products. This paper describes the conclusions we have drawn on the validity of our approach. Our findings show that many of the currently available products with integrated PV systems are initially perceived as "green" but after assessing the product on multidimensional aspects students invariably reach a more nuanced perspective, with some products failing to pass the test. Students indicated how the multidimensional assessment has made them better equipped to see through the "greenwash" and give a balanced evaluation of the real value of solar cells integrated in products. The paper will elaborate the methods used in the multidimensional assessment in more detail, illustrated with student work.
\end{abstract}

\section{INTRODUCTION}

Since 1995 Design for Sustainability (DfS) is part of the curriculum of our bachelor and master studies at Industrial Design Engineering of the Delft University of Technology. Within the educational program the faculty hosts a minor on Sustainable Design Engineering since 2008. An academic minor is a university student's secondary field of study or specialization during their undergraduate studies. The minor has been highly useful as a platform to pilot new ways of teaching engineering for sustainable development.

Instead of having students make Life Cycle Assessments (LCA) and introduce them to straightforward checklists to improve their product designs, we wanted to challenge our students to develop a critical understanding of sustainability and use multidimensional assessments to back up their findings. Sustainability is not just about environmental benefit but also about useful products and added value. This paper describes our educational approach in one of the courses within the minor of Sustainable Design Engineering, the photovoltaics practicum. Our objective in this paper is to illustrate how such a multidimensional assessment works in practice and how it has helped students develop a more critical, systemic perspective on sustainability. 
In section 2 the pedagogical structure of the practicum is given illustrated by examples of student work. In section 3 a review of the students' evaluations is presented and the paper ends with a discussion, conclusions and recommendations.

\section{PHOTOVOLTAICS PRACTICUM}

The solar energy industry is currently one the fastest growing industries in the world. With declining prices and increasing efficiencies, solar cells may become promising energy harvesters in consumer products. In this practicum our students are asked to disassemble and study a product powered by solar cells. The objective is to learn (hands-on) how these products are constructed, and to assess the practical, technical and environmental feasibility.

\subsection{Approach}

Students work in teams of 4 to 5 people. At the end of the ten week course the teams have to deliver a report and poster presentation. Together these two deliverables constitute the final grade.
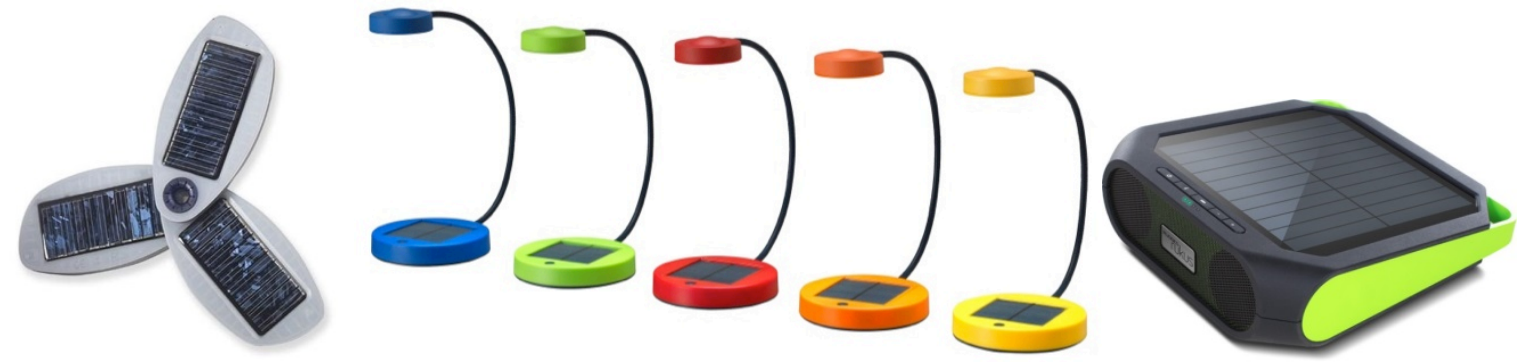

Figure 1: Examples of solar products used in the practicum: the Solio solar powered charger (Solio 2015), the IKEA Sunnan solar lamp (IKEA 2014) and the ETON Rugged rukus Bluetooth speaker (Eton 2014).

During the Photovoltaics (PV) practicum we ask the teams to assess a product with integrated PV cells e.g. a solar powered lamp, see Figure 1. The assessment is based on three sustainability factors:

1. Usability: does the PV technology offer any added value and how does this reflect on the product's usability?;

2. Technological feasibility, does the product function as it should under the intended circumstances?;

3. Environmental impact, is there a positive energy return on energy invested?

The overall learning goal is to make the students aware that when a PV product fails on one of these three factors it cannot be regarded a sustainable product. E.g. if the PV cell in its use context is too small to comply with the power consumption of the products' main function, the product will be discredited and become a gadget. When a product is difficult in use, or is multi-interpretable it will probably end up in a drawer or in the garbage. When the environmental impact of the product is higher than the environmental gain during its life, the product will not contribute to a sustainable future.

\subsection{Usability assessment}

In the first two weeks of the course students have to actively use and test the product in their own environment, the so-called "field trial". The students take turns in testing the product and have to record their findings in a diary or log, in which they describe memorable interaction moments and take pictures. Figure 2 shows such part of a diary of one of the student teams. 


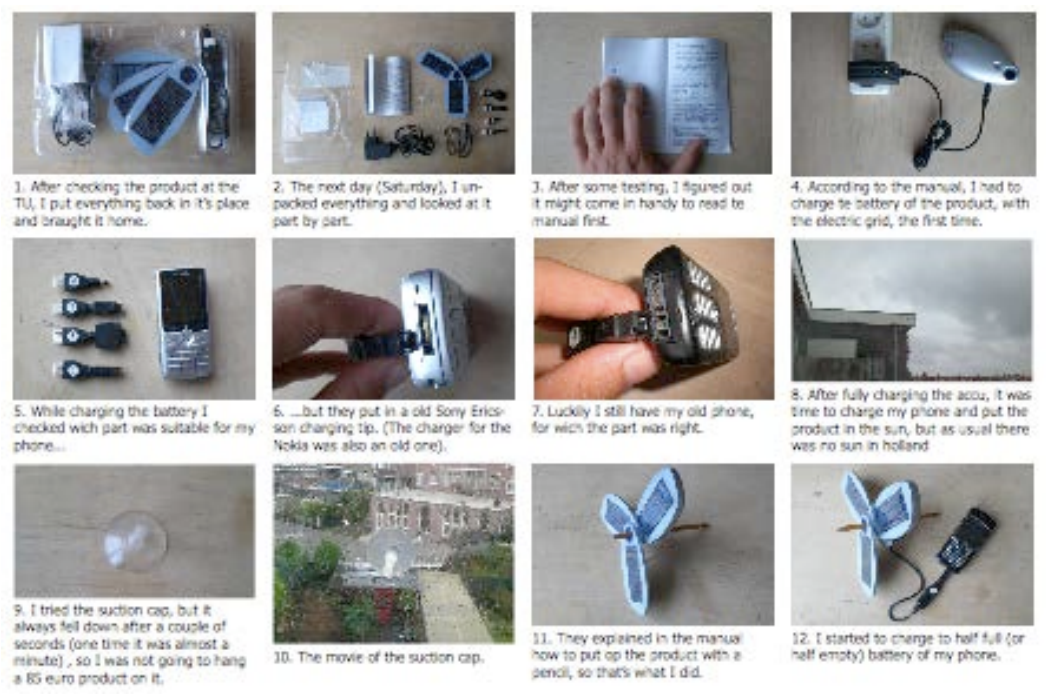

Figure 2: Diary of one of the teams, who were assigned a PV-powered phone charger.

The students should write down their expectations of the product beforehand. During the field trial they should make note of the pattern and frequency of use (which have to be clocked), the ease of use and general functioning of the product, and their frustrations and feelings of satisfaction while using the product. Finally, they have to compare their preliminary expectations with their experience after use. An important realisation from the field trial is the context-dependency of PV products. In a predominantly cloudy Netherlands (the practicum takes place in early autumn) the students quickly learn that there's often not enough solar power available to make the PV products function as they should. Some excerpts from students diaries:

“...sunlight from 10:00 am to 07:30 pm. Even after 7,5 hours of charging the lamp did not work"

And:

Day 1, 09.30 am. "Oh shit, I have to put that solar thing outside, or it won't charge."

Day 1, 11.03 pm. "It doesn't work yet. Better luck tomorrow."

There were also positive experiences:

17 September 07.30 "the sun came up. The solar panel on the lamp could charge the batteries."

17 September 20:00 "I turned the lamp on. Bright light."

17 September 02:00 "I turned the lamp off. I was still able to read."

\subsection{Technological assessment}

In weeks $3-5$ of the practicum, the task is to determine the use context and energy balance of the PVpowered product. The students have to draw up a realistic use-scenario based on their field trial and other data at hand, e.g. from the product packaging, manual or the internet. Next, they have to calculate the Energy Balance (EBR) to find out if the harvested energy matches with the used energy over a realistic time-period. The EBR is calculated by taking the ratio of the yielded energy per day/week $\left(E_{\text {in }}\right)$ over the energy demand of the product per day/week $\left(E_{\text {out }}\right)$. This ratio shows if the harvested energy matches with the energy use of the product, giving the students a sense of direction on the technological feasibility of the product, see Table 1.

Students are given lectures on calculating the EBR, but also about irradiance basics, where the difference between potential harvestable light-power in indoor situations versus outdoor are explained, which varies between 0.1 to $1000 \mathrm{~W} / \mathrm{m}^{2}$ for respectively indoor situations and bright outdoor sunlight. They have to do their own tests and measure the PV-cell in question in out- and inside situations, and also in laboratory test-cabinets (Figure 3). 
Table 1: the technological feasibility of the product-PV combination by calculating the EBR.

\begin{tabular}{ll}
\hline$E_{\text {in }} / E_{\text {out }}>10$ & $\begin{array}{l}\text { Feasible, PV system is over dimensioned, } \\
\text { optimize the system }\end{array}$ \\
\hline $1<E_{\text {in }} / E_{\text {out }}<10$ & Feasible \\
\hline $0,1<E_{\text {in }} / E_{\text {out }}<1$ & Try to adjust parameters to make it feasible \\
\hline$E_{\text {in }} / E_{\text {out }}<0,1$ & Not feasible \\
\hline
\end{tabular}
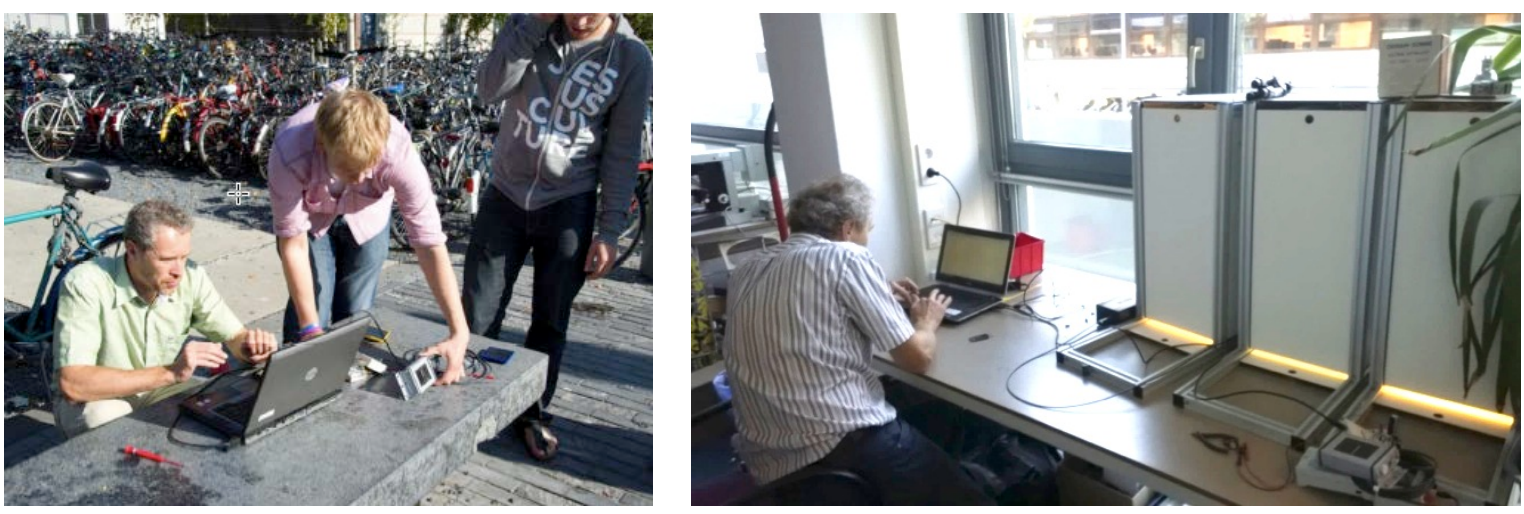

Figure 3: PV test outside, and the laboratory test using closed PV-test cabinets.

To assess if the potential harvestable power and the power production of the PV cells matches a realistic use scenario, the students are given the task to disassemble the product, measure the solar cell characteristics and determine the power and energy consumption of the product's function. Furthermore the students have to identify all components and draw up an electronic schematic (Brain 2012) which shows the interlinked connection between the power consumer (the product's main function), the intermediate accumulator (battery) and the power producer (PV cells), Figure 4.
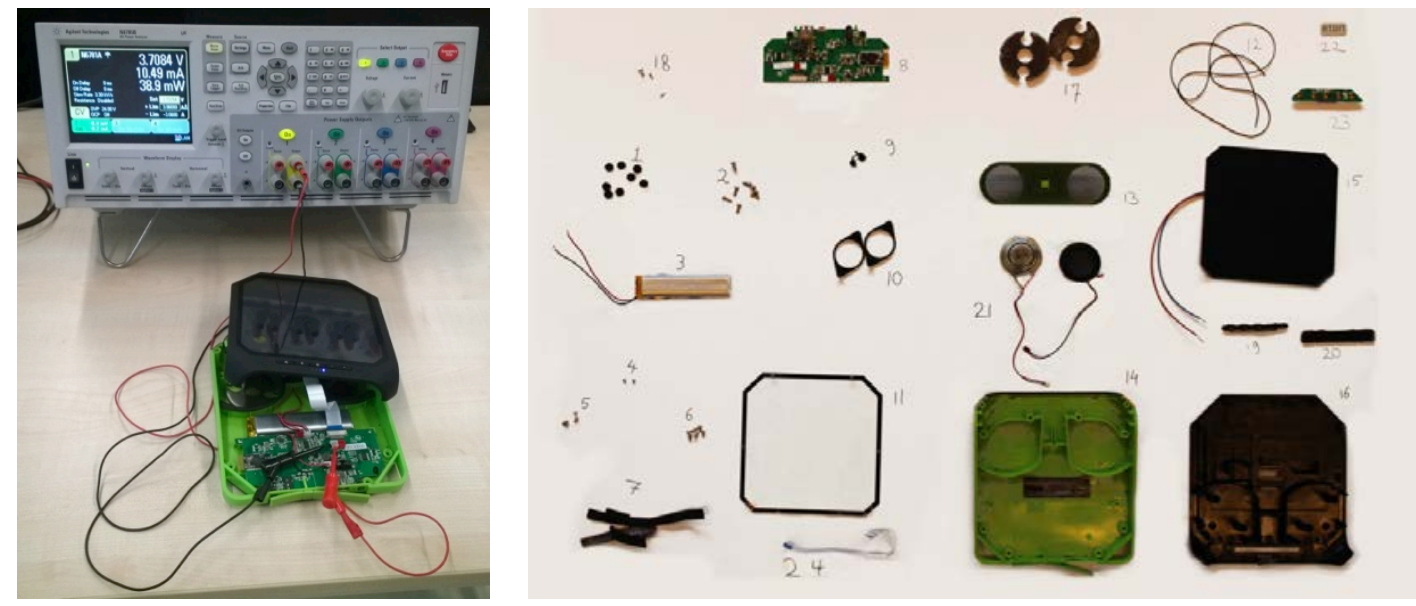

Figure 4: Measuring the power production of the PV cells and the power consumption, and an overview of components of the Eton Rugged Rukus speaker.

When the students are finished with the lab sessions they have to test the technological feasibility by means of Energy Balance Matching (S. Y. Kan 2006), questioning if the harvestable energy over a certain period matches with the power consumption of the product in the same time period. 


\section{$2.4 \quad$ Environmental assessment}

Weeks 5 to 7 are used to do the environmental assessment, where students are asked to generate a Fast-track Life Cycle Assessment (LCA) of the product (Vogtlander 2012, Goedkoop, et al. 2013, ISO 2006) and calculate the Energy PayBack Time (EPBT) of the product (U.S. DoE 2004, Peng, Lu and Yang 2013, Sullivan and Gaines 2012).

During the disassembly workshop the product is torn down to single-materal parts and, mostly electronic, components. All materials and components are documented in a Bill of Materials and Processes (BoMP), which includes the material type, weight, probable production process and origin of production; i.e. the Life Cycle Inventory ( $\mathrm{LCl}$ ). After inventorizing the students have to evaluate the potential environment impact of the product system over the total life cycle of the product. Students are asked to use the Cumulative Embodied Energy Demand indicator in MegaJoules and the Global Warming Potential in $\mathrm{kgCO}_{2}$-equivalent as their main environmental impact indicator. The first indicator can also be used to calculate the EPBT. The second indicator is the mainstream indicator for companies to show their products' environmental burden. With the LCA students should determine the main contributors on the environmental impact of the product and make a comparison with a similar product which is powered by the grid or a low-voltage charger only, and that does not make use of PV cells.

The Energy PayBack Time (EPBT) is defined as "the amount of years it will take before a PV-system produces as much energy as could be produced by the current grid-mix, using the same amount of primary energy", based on (Fthenakis and Kim 2011, Raugei 2013):

$$
E P B T=\frac{E_{P P}}{E_{\text {OUT }}}
$$

Where $E_{P P}$ is the primary energy input of the total PV system (module + components) during its whole life cycle $\left[\mathrm{MJ}_{\mathrm{p}}\right]$ and $E_{\text {OUT }}$ is the net annual primary energy savings (from the grid) due to electricity generation of the PV systems $\left[\mathrm{MJ}_{\mathrm{p}} / \mathrm{yr}\right]$.

\section{$2.5 \quad$ Reporting}

After the three assessments the student teams have to interpret all the acquired knowledge and bring this back to a scientific poster and report. Based on the findings from the field trial, lab work and the analyses they have to suggest options to improve the products' PV system, clearly argumented with facts and figures.

\section{REVIEW 2011-2014}

In the past three runs of the minor (2011-2014) 150 students have followed the same approach. This has given us a large database of multidimensional assessments on different PV powered products, and allows us to draw conclusions on the validity of our approach.

The objective was to give the student the ability to make a critical assessment on an initially perceived sustainable product by giving them tools to assess not only the environmental impact of the product but also on technology matching and usability. To give an impression on the results of the different teams over the years, an overview of quotes and calculations are given in Table 2 for four products from cohort 2011 to 2014 after performing the multidimensional sustainability assessment. 
Table 2: Multidimensional-assessment results of some of the products evaluated in 2011 to 2014.

\begin{tabular}{ll}
\hline Product & Solar Charger - group 5, cohort 2011 (Biet, et al. 2011) \\
\hline Initial & $\begin{array}{l}\text { "The initial reaction to the product was that it's a "cool" device. For the most part this is due to the concept of } \\
\text { Perception } \\
\text { charging a mobile device using solar energy." The expectations were "Long charging time before use, } \\
\text { irregular usage because of alternating weather conditions, hard to position for optimum sunscreen, expecting } \\
\text { to charge up my mobile phone and mp3 player." }\end{array}$ \\
$\begin{array}{l}\text { Technology } \\
\text { assessment }\end{array}$ & $\begin{array}{l}\text { The Energy Balance Ratio of the product is approximately 1.89, "... when energy is only required for } \\
\text { powering the common mobile devices like a mobile phone and a mp3 player, the XXXX is a feasible product." }\end{array}$ \\
Usability & $\begin{array}{l}\text { "Nevertheless after intensive testing/use of the product, certain downsides of using an unconventional power } \\
\text { assessment } \\
\text { source for charging became evident. For example, when using the device on the first day (see diary below) it } \\
\text { took approximately fifteen minutes before the mobile phone began to charge and almost three hours before } \\
\text { the products green led blinked ones"; "The concept behind the XXXX device is a great idea. It provides the }\end{array}$ \\
& $\begin{array}{l}\text { user with a great feeling of sustainable living. However, some frustrations arose. One of the typical causes of } \\
\text { frustration is the need to reposition the device, every time the position of the sun changed, in order to obtain } \\
\text { optimal sun exposure. The size and construction of the product also makes using it in public a little } \\
\text { uncomfortable. The usage of the product when on the road can lead to rather much attention. [...] The verdict } \\
\text { for the XXXX is overall positive. However, the product is best suited for specific regions where the suns } \\
\text { intensity is the greatest. Similarly, it is most suitable for people that do not mind interacting with their } \\
\text { charger." }\end{array}$
\end{tabular}

Environmental [note from the authors: in 2011 the LCA and EPBT was not introduced yet]

Assessment

Overall

Conclusion

"It was reasonable to say that we all had fairly minimal knowledge about solar powered products before partaking in the PV practicum. The least amount of understanding was how effective the product would be and the electronics behind the device. After the field trial, despite the initial frustration of having to reposition the device for optimal sun exposure, we were surprised at effectiveness of the XXXX brand. The product was able to fully charge the attached mobile phone. [...] Overall, it was concluded that solar powered products are a good concept and that they may be worth purchasing if you lived in a hot climate which experienced prolonged spells of intense sun exposure, for example in northern Australia. However, for those of us stuck in the cooler, more northern or southern parts of the world, it is most likely that solar powered products will not be efficient enough in our types of climates for a few more years to come."

\begin{tabular}{l}
\hline Product \\
\hline Initial \\
Perception
\end{tabular}

PV powered garden light - cohort 2012 (Albargothy, et al. 2012)

"All members of the group agreed that the concept of an outdoor reading light was slightly alien, although the product made sense as an outdoor entertaining light. [...] Based on the assumptions mentioned above and the group's collective knowledge of PV products: it was expected that this product would deliver a slightly underpowered light source that although being ambitious would not be quite fit for purpose. Several members of the group also expected the product to have a limited lifespan and poor quality, leading to a short product lifetime, based on their experiences of XXXX's design.

Technology assessment The EBR was calculated for two scenario and is in between 4 and 6.7, which means "the PV system is well suited to both usage scenario's."

Usability
assessment

"Having considered the usefulness of the product, most of the group were surprised about the battery life from what seemed relatively short periods of charging, which was a commendable attribute of the system. [...] ...both the diffusion of the light provided for reading and the luminosity were not fit for purpose in the eyes of the project team [...] In addition when attempting to read under the light, there was insufficient radius to read a magazine comfortably"

Environmental Calculated from an average use during june, july, august, the EPBT is approximately 25.9 years. "However if Assessment used more frequently, potentially in a commercial environment such as a bar or restaurant [...] this product would have a repayment time of approximately 8.6 years. [...] Both these scenarios would be unlikely however as the lifespan on the product's batteries is likely to be limited to around 2 to 3 years. Although replaceable, most consumers would probably not take the initiative to open up the product and replace these as it would involve unscrewing and disassembling some sections. It could therefore be suggested that the energy consumed in the manufacture of this product would never be repayed by a lot of users."

Overall Conclusion

"Based on a usage pattern of 30 days per year during the summer months [...] the product energy payback time would be approximately 26 years. Considering this figure against the lifetime of the batteries, and the difficulty a user might experience in replacing the batteries, it has to be concluded that this product is not environmentally friendly. This is an important point to note and the outcome that the project team reflected on most: although marketed to consumers as eco-friendly, these products often could provide more environmental damage than gains." 


\begin{tabular}{|c|c|}
\hline Product & Solar LED String Lights - cohort 2013 (Buquet, et al. 2013) \\
\hline $\begin{array}{l}\text { Initial } \\
\text { Perception }\end{array}$ & $\begin{array}{l}\text { "The overall expectation is that the product will work for a while but that the solar panel won't charge really } \\
\text { fast. Also because the lights work already straight out of the box, the battery might be fully charged, which } \\
\text { might influence the data. After all, until the battery runs empty we won't be certain if the solar charging } \\
\text { works." }\end{array}$ \\
\hline $\begin{array}{l}\text { Technology } \\
\text { assessment }\end{array}$ & $\begin{array}{l}\text { The Energy Balance ratio is in between } 1.75 \text { on an autumn day and } 11.9 \text { during summer. This number } \\
\text { "shows that the available input is sufficient to more than the required output. [...] Probably the designer } \\
\text { made a conscious decision here, since the user won't always have sunny days and still wants to use the } \\
\text { product then." }\end{array}$ \\
\hline $\begin{array}{l}\text { Usability } \\
\text { assessment }\end{array}$ & $\begin{array}{l}\text { "I switched the product on, but then after two hours it was already a big disappointment"; "The XXXX solar } \\
\text { lampions are a "fun-to-look-at" product, colourful and simple. They are, however, hard to assemble, don't } \\
\text { have much functionality [...] and they looked fairly cheap and poorly manufactured. This all together makes } \\
\text { the current product into a bit of a disappointment. }\end{array}$ \\
\hline $\begin{array}{l}\text { Environmental } \\
\text { Assessment }\end{array}$ & $\begin{array}{l}\text { The EPBT is in between } 2.85 \text { and } 5.44 \text { years. "If the quality of the product and the overall user experience } \\
\text { is taken into the equation, one might conclude that the product will probably be discarded after a year or } \\
\text { two. Therefore the energy payback time is too high to make this product profitable." }\end{array}$ \\
\hline $\begin{array}{l}\text { Overall } \\
\text { Conclusion }\end{array}$ & $\begin{array}{l}\text { "The solar cell works good when you charge it on a clear summer day and you want the LEDs to shine } \\
\text { bright. Therefore its practical use is quite good, as it seems to be a summer product. Sadly if we look at } \\
\text { what the real values are, technically, economically and environmentally, the product performs rather poor." }\end{array}$ \\
\hline Product & Solar lamp - group 12, cohort 2014 (Jackson, et al. 2014) \\
\hline $\begin{array}{l}\text { Initial } \\
\text { Perception }\end{array}$ & $\begin{array}{l}\text { "From our perspective, we were expecting this lamp to satisfy a number of purposes simultaneously. It will } \\
\text { serve a utilitarian function as a desk lamp providing sufficient power on demand for a reasonable length of } \\
\text { time (consistent with its ultimate solar limitations). It ought not to be a toy. [...] Rightly or wrongly, some } \\
\text { team members were expecting something special given it was his first solar product larger than a very } \\
\text { small electronic calculator." }\end{array}$ \\
\hline $\begin{array}{l}\text { Technology } \\
\text { assessment }\end{array}$ & $\begin{array}{l}\text { "Our Energy Balance result of } 1.7 \text { suggests that this product is feasible as long as a user can comply with } \\
\text { the charging requirements." [note from the authors: which is only when charged outside. Inside charging is } \\
\text { not an option] }\end{array}$ \\
\hline $\begin{array}{l}\text { Usability } \\
\text { assessment }\end{array}$ & $\begin{array}{l}\text { "Collectively, we tested this product in two parts. Firstly, we tested charging it indoors, as we were ignorant } \\
\text { of the instructions. We thought charging in a windowsill would have the same effect as charging outdoors, } \\
\text { but it was far more convenient. Secondly, we tested charging outdoors. Of course, our initial expectations } \\
\text { were disappointed only to be satisfied after complying with the manufacturer's recommendations."; } \\
\text { "The brightness achieved at full battery power closely rivalled conventional electric lamps. It was just } \\
\text { frustrating when the unit would lose power and brightness. [...]. It also became cumbersome to position the } \\
\text { battery pack ideally, relative to the sun given that it is a square unit without any devices for attaching it to } \\
\text { surfaces. The lamp unit was also not detachable. This limited potential functionality." }\end{array}$ \\
\hline $\begin{array}{l}\text { Environmental } \\
\text { Assessment }\end{array}$ & $\begin{array}{l}\text { The EBPT for the PV panel and battery pack is } 6.28 \text { to } 9.37 \text { years, when it is charged outdoor under ideal } \\
\text { usage scenario. "This analysis only really shows that the product is 'less bad' than the alternative. If we } \\
\text { want to know if the product is truly sustainable we need to take the embodied energy of many other } \\
\text { components, as well as transport and manufacturing energies. [...] Once you start adding these things up, } \\
\text { and considering that our usage scenario is optimistic, our true payback time would stretch to perhaps } 20 \\
\text { years or more. This is beyond a reasonable expectation for the lifetime of the product." }\end{array}$ \\
\hline $\begin{array}{l}\text { Overall } \\
\text { Conclusion }\end{array}$ & $\begin{array}{l}\text { "From this we can conclude that the PV cell is well matched to the battery voltage for outdoor charging. If } \\
\text { we wanted to optimize the indoor performance, one option would be to adjust the batteries to a lower } \\
\text { voltage so they would align well with the maximum power curve. This would be a waste, as the indoor } \\
\text { power seems too small to bother." }\end{array}$ \\
\hline
\end{tabular}

\section{DISCUSSION AND CONCLUSIONS}

Because this course was limited in time spent (2 ECTS, equalling 56 hours per team member) there was, unfortunately, no time for very detailed analysis and proper redesign. Students had to use already acquired skills to assess the products properly. Amongst others the environmental impact is assessed by using an LCA, which was taught in one of the parallel courses of the minor.

The student teams consisted of different disciplines ranging from industrial design, mechanical and aerospace engineers to students with an art background. The structured approach in this course 
contributed to good teamwork and high-value results, which was well appreciated by most of the students attending the course.

Our findings show that many of the currently available products with integrated PV systems (lamps, chargers, household appliances, etc.) are initially perceived as "green" and sustainable. After the multidimensional assessment students however invariably reach a more nuanced perspective, with some products failing to pass the test and others, to some surprise, passing the test. From reflections in the final reports and our evaluation sessions with the students, the students indicated how the multidimensional assessment has made them a "better" engineer, more equipped to see through the "greenwash", and give a balanced assessment of the real value of solar cells integrated in products. The course was successful in reaching our goal to teach our students critical thinking and design by assessing a product from multiple dimensions instead of only one.

\section{Acknowledgements}

We would like to thank all our students who have participated this course over the years and given their feedback on the course.

\section{References}

Albargothy, Ahmed, Rick Boellaard, James Deighton, Arend Jan de Graaff, and Tim Koning. PV practicum, an investigation into the feasiblity of PV products, Solvinden garden ligth. Delft: Student project report, 2012.

Biet, Jonathan, Freddie Wotton, Kwabena Ofori, and Lara Olivera. PV practicum - Solio report. Delft: Student project report, 2011.

Brain, Marshall. How Solar Yard Lights Work. 2012. http://home.howstuffworks.com/solar-light.htm.

Buquet, Romy, Steven Burger, Joeri Simonian, and Sander van Welsem. PV Cell practical report, XXXX Solar LED Strings Lights. Delft: Student project report, 2013.

Eton. Rugged rukus | Eton. 2014. http://www.etoncorp.com/en/productdisplay/rugged-rukus (accessed 2014).

Francis, A., L. Husarova, V.C. van 't Laar, C. Lau, and A. Visser. IO3836 - PV practicum, Practicum report - group 3. Delft: Student project report, 2014.

Fthenakis, V.M., and H.C. Kim. "Photovoltaics: Life-cycle analyses." Solar Energy 8, no. 85 (2011): 16091628.

Goedkoop, Mark, Reinout Heijungs, Mark Huijbregts, An de Scrhijver, Jaap Struijs, and Rosalie van Zelm. ReCiPe 2008. Amersfoort: PRe Consultants, 2013.

IKEA. Sunnan Lamp Campaign. 2014. http://www.ikea.com/ms/nl_NL/about_ikea/our_responsibility/ikea_social_initiative/sunnan_lamp_camp aign.html.

ISO. "ISO 14040:2006." Environmental management - Life Cycle Assessment - Principles and framework. ISO, 2006.

Jackson, Alan, Nick McDonald, Kostas Fines, and Sjon Roelofsen. Ikea sunnan lamp. Delft: Student project report, 2014.

Kan, Sioe Yao. Energy Matching, key towards the design of sustainable photovoltaic powered products. Delft: PrintPartners Ipskamp, Rotterdam, 2006.

Kan, Sioe Yau, and Ruben Strijk. "Towards a more efficient energy use in photovoltaic powered products." Journal of Power Sources 2006, no. 162 (2006): 954-958.

Peng, Jinqing, Lin Lu, and Hongxing Yang. "Review on life cycle assessment of energy payback and greenhouse gas emission of solar photovotaic systems." Renewable and Sustainable Energy Reviews (Elsevier), no. 19 (2013): 255-274.

Porter, M.,. "The Economic Performance of Regions." Regional Studies 37, no. 6-7 (2003): 545-546.

Raugei, M. "Energy Pay-back time: methodological caveats and future scenarios." Progress in Photovoltaics, no. 21 (2013): 797-801. 
Schermer, Raisa, Laureen Smit, Leoni Vogelsang, Linda Vos, and Lian Wu. Eton Rugged Rukus, A solar powered speaker- PV practicum. Delft University of Technology, Industrial Design Engineering, Delft: Student project report, 2014.

Solio. 2015. http://www.solio.com.

Sullivan, J.L., and L. Gaines. "Status of life cycle inventories for batteries." Energy Conversion and Management, 2012: 134-148.

U.S. DoE. PV FAQs, What is the energy payback for PV? Washington, D.C., January 2004.

Vogtlander, Joost. LCA, a practical guide for students, designers and business managers. Delft: VSSD Science and Technology, 2012. 